\title{
トゥモロコシサイレージにおける破砕処理が乳牛の 炭水化物およびタンパク質利用に及ぼす影響
}

\author{
谷川珠子 ${ }^{1} \cdot$ 大坂郁夫 $^{2} \cdot$ 川本 哲 ${ }^{1}$ 原 悟志 ${ }^{1}$ \\ 1 北海道立畜産試験場, 北海道新得町 081-0038 \\ 2 北海道立中央農業試験場, 北海道長沼町 069-1395
}

\begin{abstract}
(2009. 7. 6 受付, 2009. 10. 5 受理)
要 約 トウモロコシサイレージ（CS）における破砕処理が，乳牛の養分利用に及ぼす影響を検討し た. 黄熟期に設定切断長 $17 \mathrm{~mm}$ で調製した未破砕 CS，および切断長は同様としローラ間隔 $5 \mathrm{~mm}$ で破 砕処理して調製した破砕 CS を用い，飼料全体の粗タンパク質（CP）含量が $14 \%$ となるように，各 CS に大豆粕を $84: 16$ (乾物比) の割合で混合したものを供試した (未破砕区, 破砕区)。これらをルーメン および十二指腸カニューレを装着したホルスタイン種乾乳牛 3 頭に給与した.CS の化学成分は破砕処 理の影響がなかったが，破卆区は乾物，CP およびデンプン摂取量が有意に高かった $(P<0.05)$.ルー メン内のデンプン消化率は破砕区が $30 \%$ 高い傾向にあったが $(P=0.08), N D F$ の消化率は区間に差が なかった。総消化管におけるデンプン消化率は破砕区で高く $(P<0.05)$, CS の TDN は破砕 CS で $3.5 \%$ 高まった。ルーメン液の $\mathrm{pH}$ および反忽時間は区間に差がなく, 採食時間は破砕区で短かった（ $P$ $<0.05)$. ルーメン内可消化有機物量に対する微生物体窒素合成効率は区間に差がなく, 破砕 CSに適し た併給タンパク質飼料の給与方法について検討が必要と考えられた. 以上より, 設定切断長が $17 \mathrm{~mm} の$ とき, 破砕処理をしても総咀嚼時間は変化せず，NDF 消化率を低下させずに，デンプンの利用え進が可 能であった.
\end{abstract}

日本畜産学会報 81 (1), 11-19, 2010

トウモロコシは登熟に伴い，収量および乾物含量が増 加するだけではなく，総体に占める子実割合が高まるた め, デンプン含量が増加する。しかし，登熟に伴い子実 表面のデンプンがルーメン内微生物の消化を受けにくい 角質状デンプンに変化するため, デンプンの消化率は低 下する (Philippeau と Michalet-Doreau 1997).さらに, 登熟に伴い中性デタージェント繊維 (NDF) の消化率も 低下する (Balら 1997 ; Andrae ら 2001). 谷川ら (2008) は, 乳熟期に比べ黄熟期のトウモロコシサイレージ (CS) では, ルーメン内におけるデンプンおよびNDF 消化率 が 20\% 以上低く, ルーメン内可消化炭水化物量が減少 するために微生物体窒素の合成効率が低い傾向にあるこ とを報告し，黄熟期以降ではルーメン内の養分消化率を 高める必要があることを示した。

黄熟期以降の CS の養分消化率を高めるために，飼料 用卜ウモロコシの破砕処理技術が 1980 年代にヨーロッ パで開発され，北海道では 2000 年頃から利用され始め た。これまでのトウモロコシの収穫では，ハーベスタの フィードローラでトウモロコシを引き込み, カッター
ヘッドで細断した後，ブロワーで吹き上げられる．破砕 処理とは，カッターヘッドとブロワーの間に溝の付いた 2 本のローラからなる装置を取り付け，回転するローラ の間隙を通すことで細断したトウモロコシをすり潰す行 程のことである．破砕処理によって，子実の破壊による デンプンの暴露, 茎葉部の損傷による脆弱化および表面 積の増加が起こるため, ルーメン内の微生物発酵を受け やすくなり，消化率が高まることが期待される.

破砕処理したCS の in situ デンプン消失率, 総消化管 における養分消化率，乳生産へ及ぼす影響は多くの試験 で報告されている（Balら 1997 ; Bal ら 2000 ; Weiss と Wyatt 2000 ; Johnson ら 2002a). 破砕処理による子実お よび茎葉部の損傷は，総消化管における養分消化率だけ ではなく,ルーメン内における養分消化率に影響し, ルー メン内可消化養分量の変化はルーメン内微生物の合成量 に影響すると考えられるが，ルーメン内の養分消化率や 微生物体窒素合成についての報告は少ない (Johnson ら 2002a, b). 破砕処理したCS のルーメン内の発酵様相を 明らかにすることは，破砕処理 CS の栄養を効率的に利

連絡者：谷川珠子（fax: 0156-64-5349, e-mail : t.tanigawa@agri.pref.hokkaido.jp） 
用した併給飼料の給与方法を検討するためにも重要であ る.

そこで本研究では，破砕処理 CS を効率的に利用した 乳生産を図ることを目指し, 破砕処理の有無が乾乳牛の 養分利用に及ぼす影響を検討した。

\section{材料および方法}

\section{1. 供試飼料, 供試動物および飼養管理}

ルーメンおよび十二指腸カニューレを装着したホルス タイン種乾乳牛 3 頭（試験開始時の平均体重 $683 \pm 79$ $\mathrm{kg}$ ）を供試した.

トウモロコシの品種は39B29 (早生の早) を用い, 北海 道立畜産試験場内の戋場で栽培した。供試 CSは2003/ 10/10 (黄熟中期) に, 自走式八ーベス夕で設定切断長を $17 \mathrm{~mm}$ として, 破砕処理なし（未破砕 CS）またはローラ 間隔 $5 \mathrm{~mm}$ で破砕処理し (破砕 CS), それぞれ音産試験 場内の 50 t容のバンカーサイロに詰め込み, シートをか けて密閉した.サイロは調製後50日経過した後開封し, CSを供試した。

それぞれのCSに飼料全体の粗タンパク質 (CP) 含量 が 14\% となるように大豆粕 (大豆油かす; 丹波屋, 北海 道) を混合し, 残食量が原物で給与量の $10 \%$ となるよう に飽食給与した。未破砕 CS および破砕 CS 給与した 区をそれぞれ未破砕区および破砕区とした．CS と大豆 粕の乾物混合比は未破砕区, 破砕区とも $84: 16$ であっ た。飼料は1日1回 10：30に給与した。ミネラル剤（バ イミルク; 日本全薬工業, 福島) $200 \mathrm{~g}$ をップドレス給 与し，水は自由摂取とした。

試験期間は予備期 9 日間, 本期 5 日間とし, 破砕区, 未破砕区の順で試験を行った。養分消化率は酸化クロム を指標として推定した，酸化クロム，フスマおよび糖蜜 を酸化クロム含量が $10 \%$ (乾物比) となるように混合し 成型したペレットを作成し, 予備期 9 日間および本期 3

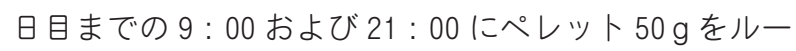
メンカニューレから投与した.

供試動物へのカニューレの装着および飼養管理につい ては, 北海道立畜産試験場動物実験規約に基づいて行っ た.

\section{2. 試料採取および分析方法}

飼料摂取量は, 本期 1 5 日目に給与量から残食量を 差引くことにより求め, 5 日間の平均値を統計分析に用 いた. 本期 1 3 日目の 9:00に給与CS のサンプルを, $9 ： 00$ および 21：00 に䔬サンプルを直腸から採取し, $60^{\circ} \mathrm{C}$ で 48 時間通風乾燥した後, CS サンプルの一部お よび個体ごとの糞サンプルをそれぞれ 3 日分混合して 1 $\mathrm{mm}$ のスクリーンをつけたウィレー型粉砕機で粉砕し た. 通風乾燥したCSサンプル約 $200 \mathrm{~g}$ を, 目開き 19.0 , 9.50 および $1.18 \mathrm{~mm}$ の篣および受け典をつけた電磁式 篣振とう器を用いて篩別し, CS の粒度分布を測定した。
給与した大豆粕のサンプルは, 本期 1日目の 9：00 に採 取し, 通風乾燥せずに粉砕した。十二指腸内容物は本期 開始から 3 日間，1 日ごとに 1 時間ずつ採取時間をずら して 3 時間間隔で十二指腸カニューレから約 $500 \mathrm{~mL}$ 採 取し，個体ごとに3日分を混合した。 十二指腸内容物の 一部をアンモニア態窒素濃度 $\left(\mathrm{NH}_{3}-\mathrm{N}\right)$ 濃度測定のため, $-28^{\circ} \mathrm{C}$ で凍結保存し, 残りは凍結乾燥したあと粉砕し た. 給与飼料, 粪および十二指腸内容物の乾物, 粗灰分, $\mathrm{CP}$, 粗脂肪およびNDF含量は常法 (自給粗飼料品質評価 研究会 2001)に準じて分析した. デンプンはTotal starch assay kit (Megazyme, Co., Wicklow, Ireland) を用いて測 定した。糞および十二指腸内容物のクロム含量はリン酸 カリ試薬法（武政 1992）を用いて測定した.

本期 4 日目の $8: 00$ から 5 日目の $8: 00$ までの 24 時 間の供試牛の行動をビデオで撮影し, 行動型を採食, 反 㫚，立位および横卧の 4 区分に分けて，1 分間隔で記録 し，採食時間，反媰時間およびそれらを合計した総咀嚼 時間を算出した。

本期 5 日目の $10: 00$ から翌日の $10 ： 00$ まで3 時間お きにルーメンフィステルからルーメン液約 $500 \mathrm{~mL}$ を採

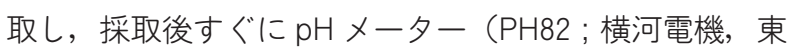
京)により, $\mathrm{pH}$ を測定した後, 一部を $\mathrm{NH}_{3}-\mathrm{N}$ 濃度および 揮発性脂肪酸（VFA）濃度の測定までー $28^{\circ} \mathrm{C}$ で凍結保存 した. 十二指腸内容物およびルーメン液の $\mathrm{NH}_{3}-\mathrm{N}$ 濃度は インドフェノール法 (日本分析化学会北海道支部 1981) に準じて測定した。ルーメン液のVFA 濃度はガスクロ マトグラフ (GC-17A ; 島津製作所, 京都) を用いて測定 した。採取したルーメン液の一部を 4 重ガ一ゼで漉し, 個体ごとに混合して，ルーメン液中の微生物体の分離に 用いた.ルーメン液からの微生物体の分離はS mith と McAllan（1974）の方法，プリン体含量の測定はZinn と Owens（1986）の方法に準じて行った.

\section{3. 各種指標の計算および統計処理}

十二指腸内容物流量および粪量は，1日の酸化クロム 投与量を十二指腸内容物および䔬の酸化クロム濃度で除 して算出し，消化管部位別のみかけの養分消化率を下記 の式を用いて算出した.

*ルーメン内消化率 $=($ 摂取した養分量一十二指腸へ 移行した養分量) $/$ 摂取した養分量 $\times 100$

$*$ 総消化管消化率 $=$ (摂取した養分量一糞中へ排泄さ れた養分量)/摂取した養分量 $\times 100$

給与飼料の TDN 含量は, NRC 乳牛飼養標準 (NRC 2001）に従い，飼料中の非繊維性炭水化物（NFC）, CP, 粗脂肪およびNDF 含量に，それぞれの総消化管消化率 を乗じることにより算出した。

$* T D N=$ 可消化NFC + 可消化 $\mathrm{CP}+$ 可消化粗脂肪 $\times$ $2.25+$ 可消化NDF-7

十二指腸へ移行した総窒素に占める微生物体由来の窒 素割合は, 微生物体のプリン体濃度を十二指腸内容物の 
プリン体濃度で除して求めた。 十二指腸への微生物体窒 素および飼料由来の窒素移行量は下記の式を用いて算出 した.

*微生物体由来窒素移行量 $=$ 十二指腸への窒素移行

量 $\times$ 微生物体窒素割合

* 飼料由来窒素移行量 $=$ 十二指腸への窒素移行量 -

(微生物体窒素移行量 $+\mathrm{NH}_{3}-\mathrm{N}$ 移行量)

処理間の有意差の検定は対のある $\mathrm{t}$ 検定を用い，有意 水準は $P<0.05$ とした。

\section{結果および考察}

\section{1. 給与飼料の化学成分, CS の粒度分布および養分 摂取量}

未破砕 CS, 破砕 CS および給与飼料の化学成分およ びCS の粒度分布を表 1 に示す. 未破砕 CS と破砕 CS でいずれの化学成分も差はなく, 黄熟期の卜ウモロコシに おいて破砕処理は CS の化学成分に影響しないことが示 された．大豆粕を混合した飼料全体でも化学成分に差は なかった. Andraeら (2001)およびEbling と Kung (2004) も, 破砕処理はCS の化学成分に影響しないことを報告 しており，本試験の結果はこれらと一致するものであっ た. 未破砕 CS の $19.0 \mathrm{~mm}$ 以上の飼料片割合は $14 \%$ で あったのに対し, 破砕CSでは 1\% と大きく低下しており, $1.18 \mathrm{~mm}$ 以下の飼料片割合が $24 \%$ と高まった. Andrae ら（2001）およびCooke と Bernard（2005）も, 本試験
と同様に破砕 CS では $19 \mathrm{~mm}$ 以上の飼料片割合が低下 し, $10 \mathrm{~mm}$ 以下の飼料片割合が高まることを示してい る.

乾物および養分摂取量を表 2 に示す。乾物摂取量は未 破砕区 $11.2 \mathrm{~kg} /$ 日，破砕区 $12.5 \mathrm{~kg} /$ 日で，破砕区が高く $(P<0.05)$, 給与飼料の成分含量は区間に差がなかった ため, 乾物摂取量の高い破砕区で CP およびデンプン摄 取量が高く $(P<0.05), N D F$ およびNFC 摂取量も高い 傾向にあった。本試験と同様に, Balら（2000）および Andrae ら (2001) も，破砕処理によって乾物摂取量は増 加する傾向にあることを示している. Andrae ら (2001) は, 破砕 CS は未破砕 CS より飼料片の粒度が小さく, ルーメンからの通過速度が高まるため (Weigand ら 1993), 破砕処理 CS 給与時に乾物摂取量が増加すると考察して いる.さらに, Dhimanら (2000)は, 破砕処理によりCS 調製時の詰め込み密度が高まり, 発酵品質が向上するた め, 乾物摂取量が増加したと考察している. 本試験では, CS の発酵品質は測定していないが, Dhiman ら (2000) と同様に, 破砕 CS で発酵品質が向上していた可能性が ある．破砕処理によるCS の飼料片粒度の低下と発酵品 質の向上が，本試験の破砕区でも乾物摂取量が高まった 原因と考えられる.

\section{2. 消化管部位別の消化率およびTDN}

ルーメン内および総消化管における見かけの消化率お よび給与飼料のTDNを表 3 に示す．有機物（OM）およ

Table 1 Nutrient composition of experimental corn silage, soybean meal and diets and particle size distribution of corn silage

\begin{tabular}{|c|c|c|c|c|c|c|}
\hline & & \multicolumn{2}{|c|}{ Corn silage $^{1}$} & \multirow{2}{*}{$\begin{array}{l}\text { Soybesn } \\
\text { meal }\end{array}$} & \multicolumn{2}{|c|}{$\operatorname{Diet}^{2}$} \\
\hline & & Unprocessed & Processed & & Unprocessed & Processed \\
\hline \multicolumn{7}{|l|}{ Nutrient composition } \\
\hline $\mathrm{DM}$ & $(\%)$ & 31.7 & 29.3 & 90.4 & 35.4 & 33.1 \\
\hline OM & $(\% \mathrm{DM})$ & 95.7 & 95.1 & 93.3 & 95.3 & 94.8 \\
\hline $\mathrm{CP}$ & $(\% \mathrm{DM})$ & 7.5 & 7.5 & 49.8 & 14.4 & 14.5 \\
\hline NDF & $(\% \mathrm{DM})$ & 51.1 & 50.7 & 10.2 & 44.3 & 44.0 \\
\hline Starch & $(\% \mathrm{DM})$ & 20.8 & 21.1 & 0.8 & 17.5 & 17.7 \\
\hline NFC & $(\% \mathrm{DM})$ & 36.2 & 35.6 & 32.0 & 35.4 & 35.0 \\
\hline \multicolumn{7}{|l|}{ Particle size distribution } \\
\hline$>19.0 \mathrm{~mm}$ & $(\%)$ & 14 & 1 & - & - & - \\
\hline$>9.50 \mathrm{~mm}$ & $(\%)$ & 10 & 8 & - & - & - \\
\hline 1.18 to $9.50 \mathrm{~mm}$ & $(\%)$ & 68 & 68 & - & - & - \\
\hline$<1.18 \mathrm{~mm}$ & $(\%)$ & 8 & 24 & - & - & - \\
\hline
\end{tabular}

DM, Dry matter; OM, Organic matter ; CP, Crude protein ; NDF, Neutral detergent fiber ; NFC, Non fibrous carbohydrates

- ; Not determined

${ }^{1} \mathrm{CS}$ was harvested at yellow ripe stage of maturity. Roller clearance for processed silage was set at $5 \mathrm{~mm}$ and theoretical length of cut for processed and unprocessed CS was $17 \mathrm{~mm}$.

${ }^{2}$ Diet was a mixture of corn silage and soybean meal at proportion of $84: 16$ (DM basis) 
びCP消化率は区間に差がなかった。他の研究において 破砕処理は総消化管における OM およびCP消化率に影 響しないことが示されており（Balら2000; Johnson ら 2002b; Cooke と Bernard 2005), 本試験の結果もこれら の報告と一致した。

ルーメン内の NDF 消化率は区間に差がなかった。本 試験と同様に，破砕処理をしてもルーメン内の NDF 消 化率は変化しないことが報告されているが (Johnson ら 2002a), in situ NDF 消失率は破砕 CS で高まることが示 されており (Andraeら 2001), 破砕処理の影響がin situ と in vivo で異なっている. 破砕処理によりCS 飼料片の表 面積は増加するものの, 飼料片のサイズは低下し, ルー メンの通過速度が高まるため（Schwab ら 2002 ; Ebling
とKung 2004)，結果として in vivoでは破砕処理をして もルーメン内の NDF 消化率に差がなかった可能性があ る. 総消化管における NDF 消化率は未破砕区 $62.1 \%$ に 対して，破砕区 $66.1 \%$ で破砕処理によって約 4\% 高まる 傾向にあり $(P=0.10)$, この結果は, 総消化管における NDF 消化率が3〜9\% 高まることを示した過去の報告 と一致した (Weiss と Wyatt 2000 ; Johnson ら 2002a ; Cooke と Bernard 2005). しかし, Balら (2000) および Dhiman ら（2000）は，破砕 CS 給与時にNDF消化率が 低下することを示した。彼らは，破砕 CS は以下に示す ようにデンプン消化率が高まるために繊維分解菌の活性 が低下し，さらに飼料片粒度が小さいためルーメン内容 物の通過速度が高まり, NDF 消化率が低下すると考察し

Table 2 Effects of feeding of mechanically processed corn silage on nutrient intake of cows

\begin{tabular}{|c|c|c|c|c|}
\hline & & \multicolumn{2}{|c|}{ Corn silage } & \multirow{2}{*}{$\begin{array}{l}\text { Significant } \\
\text { difference }\end{array}$} \\
\hline & & Unprocessed & Processed & \\
\hline DM & (kg/day) & $11.2 \pm 0.5$ & $12.5 \pm 0.6$ & $*$ \\
\hline OM & (kg/day) & $10.7 \pm 0.5$ & $11.9 \pm 0.6$ & $*$ \\
\hline $\mathrm{CP}$ & (kg/day) & $1.6 \pm 0.1$ & $1.8 \pm 0.1$ & $*$ \\
\hline NDF & (kg/day) & $1.8 \pm 0.1$ & $2.2 \pm 0.1$ & $P=0.06$ \\
\hline Starch & (kg/day) & $2.8 \pm 0.1$ & $3.2 \pm 0.2$ & $*$ \\
\hline NFC & (kg/day) & $4.0 \pm 0.2$ & $4.4 \pm 0.2$ & $P=0.07$ \\
\hline
\end{tabular}

Mean \pm standard deviation

${ }^{1} * P<0.05$

Table 3 Effects of feeding of mechanically processed corn silage on apparent ruminal digestibility, total tract digestibility and total digestible nutrients (TDN) of diets

\begin{tabular}{|c|c|c|c|c|}
\hline & & \multicolumn{2}{|c|}{ Corn silage } & \multirow{2}{*}{$\begin{array}{l}\text { Significant } \\
\text { difference }\end{array}$} \\
\hline \multicolumn{2}{|l|}{ Item } & Unprocessed & Processed & \\
\hline \multicolumn{5}{|c|}{ Ruminal digestibility } \\
\hline $\mathrm{OM}$ & $(\%)$ & $56.5 \pm 9.1$ & $60.6 \pm 1.0$ & NS \\
\hline NDF & $(\%)$ & $54.6 \pm 14.0$ & $56.7 \pm 1.2$ & NS \\
\hline Starch & $(\%)$ & $53.9 \pm 24.9$ & $86.0 \pm 5.7$ & $P=0.08$ \\
\hline NFC & $(\%)$ & $68.7 \pm 6.8$ & $73.2 \pm 4.3$ & NS \\
\hline \multicolumn{5}{|c|}{ Total tract digestibility } \\
\hline $\mathrm{OM}$ & $(\%)$ & $77.3 \pm 1.5$ & $77.0 \pm 3.2$ & NS \\
\hline $\mathrm{CP}$ & $(\%)$ & $80.7 \pm 1.1$ & $81.3 \pm 1.2$ & NS \\
\hline NDF & $(\%)$ & $62.1 \pm 2.8$ & $66.1 \pm 1.9$ & $P=0.10$ \\
\hline Starch & $(\%)$ & $96.7 \pm 1.6$ & $99.9 \pm 0.1$ & $*$ \\
\hline NFC & $(\%)$ & $89.3 \pm 1.8$ & $92.9 \pm 1.0$ & $*$ \\
\hline TDN & (\% DM) & $68.1 \pm 1.1$ & $71.2 \pm 1.1$ & $*$ \\
\hline
\end{tabular}

Mean \pm standard deviation

${ }^{1} \mathrm{NS}$ : Not significant $(P>0.10), \quad * P<0.05$ 
ている. Bal ら（2000）は, 設定切断長が $9.5 \mathrm{~mm}$ のとき, ローラ間隔 $1 \mathrm{~mm}$ で破砕処理すると NDF 消化率は大き く低下することを示しており, 設定切断長が短い場合に ローラ間隔を狭くして破砕処理すると，飼料片粒度が低 下し, ルーメンの発酵速度および通過速度が大きく高ま るため, NDF 消化率が低下する可能性がある. 本試験の ように，設定切断長を $17 \mathrm{~mm}$ と長くし，ローラ間隔を 5 $\mathrm{mm}$ とした破砕処理条件では, ルーメン内の NDF 消化 率は変化しないことが示唆された。

ルーメン内におけるデンプンの消化率は未破砕区 53.9\% であったのに対して，破杂区 $86.0 \%$ と約 30\% 高 まる傾向にあった $(P=0.08)$. 破砕処理によるルーメ ン内デンプン消化率の向上は, in situ (Bal ら 2000) およ び in vivo (Johnsonら 2002a) の結果と一致している. 破砕 CS は未破砕 CS に比べて, 損傷を受けた子実の割 合が高く, 内部の消化されやすいデンプンが露出してい るため, ルーメン微生物にデンプンが利用されやすくな ると考えられている (Johnson ら 2002c ; Ebling と Kung 2004). 実際, 本試験とほぼ同様の飼料サンプルを用いた in situ 分析において, 破砕 CS ヘのデンプン分解菌の付 着および增死促進が確認されている (Kozakai ら 2007). Balら (2000) およびAndraeら (2001) は, in situにおい て，24 時間のデンプン消失率は未破砕に比べ，破砕処理 CS で 10～20\%高まることを示し，Johnson ら (2002a) は in Vivoにおいて, 破砕処理によりルーメン内のデン プン消化率が 15～20\% 高まることを報告している. 本 試験のルーメン内のデンプン消化率は, 未破砕区に比 ベ，破砕区で約 30\% 高く, Johnson ら (2002a) の報告よ りも消化率が大きく向上した. Johnsonら（2002a）では 飼料中のCS 割合が乾物比で $26 \%$ であったのに対して, 本試験の飼料中 CS 割合は $84 \%$ と高かったため, 破砕 処理がデンプン消化率に及ばす効果が表れやすかったと 考えられる. 総消化管においても破砕区でデンプン消化 率が高かった $(P<0.05)$. 本試験の結果之同様に, 総消 化管におけるデンプン消化率が破砕処理によって高まる ことは多くの試験で報告されている (Johnson ら 2002a； Ebling と Kung 2004 ; Cooke と Bernard 2005). しかし, 総消化管におけるデンプン消化率の向上は本試験および 過去の報告ともに3〜 5\% 程度であり，ルーメン内のデ ンプン消化率に比べて破砕処理の影響は小さかった。破 砕処理は特にルーメン内のデンプン消化率の向上に大き く影響することが示された.

給与飼料の化学成分は区間に差がなかったが (表 1), 総消化管 NDF 消化率は破砕区で高い傾向にあり $(P=$ 0.10), NFC 消化率も破砕区で高かったため $(P<0.05)$, 給与飼料の TDN は未破砕区 $68.1 \%$ ，破砕区 $71.2 \%$ で破 砕区が3\%向上した $(P<0.05)$. Johnson ら (2002a) も, 破砕処理によって飼料全体の TDN が約 $2 \%$ 高まる ことを示しており，本試験の結果と一致した．大豆粕の
TDN を乾物中 $89.6 \%$ （農業技術研究機構 2001）とし, 各 区のCS と大豆粕の混合比からCS の TDN を試算する と，未破砕 CSは $64.5 \%$ ，破砕 CSは $68.0 \%$ となり，設 定切断長 $17 \mathrm{~mm}$ の条件では, ローラ間隔 $5 \mathrm{~mm}$ の破砕処 理によってCS の TDN は 3.5\% 高まることが示された. Cooke と Bernard（2005）は，ローラ間隔 1 2 mm で破 砕処理の効果が得られ, 間隔が $8 \mathrm{~mm}$ ではすり潰し効果 が十分に得られないため, 養分消化率は向上しないこと を示したが，本試験の結果からローラ間隔 $5 \mathrm{~mm}$ でも 1 〜2 mm で破砕処理したときと同程度にデンプン消化率 およびTDNを高められることが示唆された.

\section{3. 十二指腸への窒素移行量, 微生物体窒素合成およ びルーメンのアンモニア態窒素濃度}

窒素摂取量, 十二指腸への窒素移行量および微生物体 窒素合成効率を表 4 に, 飼料給与 24 時間後までのルー メン液の $\mathrm{NH}_{3}-\mathrm{N}$ 濃度の推移を図 1 に示す.ルーメン内に おける飼料由来の CP 消化率は区間に差がなかったが, 破砕区は窒素摂取量が高いため $(P<0.05)$, 飼料由来の $\mathrm{CP}$ の可消化量は破砕区で高い傾向にあった $(P=0.09)$. 破砕区は未破砕区に比べ，十二指腸への窒素移行量は多 い傾向にあったが $(P=0.10)$, 微生物体由来および飼 料由来の窒素移行量は区間に差がなく, ルーメン内可消 化 OM 量に対する微生物体窒素合成量（微生物体窒素合 成効率）も区間に差がなかった。 OM 摂取量が増加する 之, 十二指腸への窒素移行量も増加することが示されて おり (Clarkら 1992)，破砕区で十二指腸への窒素移行量 が高かったのは，OM 摂取量が多かったことが要因で あった可能性がある.

破砕区の $\mathrm{NH}_{3}-\mathrm{N}$ 濃度は, 飼料給与 5.5 時間後に未破砕 区に比べて有意に高く $(P<0.05)$ ，それ以降も破砕区 で高く推移する傾向にあり，これは破砕区で CP 摂取量 が高く（表 2), 可消化窒素量が多い傾向にあったため （表 4）と考えられた。微生物体窒素移行量および微生物 体窒素合成効率は区間に差がなかった。微生物体窒素の 合成量はルーメン内の炭水化物とタンパク質の分解速度 および分解量が同期化することによって増加するといわ れており (Herrera-Salsana ら 1990), 本試験の破砕区は 未破砕区に比べ，ルーメン内のデンプン消化率は高く， 可消化窒素量が多い傾向にあったにも関わらず，微生物 体窒素移行量は増加しなかった。破砕処理 CS 給与時に 適した併給タンパク質飼料の給与方法について, 今後検 討が必要である. また, 本試験で得られたルーメン内可 消化 OM (OMDR) 当たりの微生物体窒素合成効率は 14.1

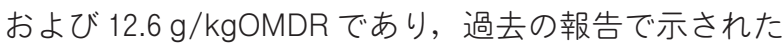
13 32 g/kgOMDR (Herrera-Salsana ら 1990 ; Aldrich ら 1993）の下限に近い値であった。これらの報告では泌乳 牛を用いているが, 本試験では乾乳牛を用いており, 乾 物摂取量が少なく, ルーメン内容物の通過速度が低く, 微生物体窒素合成効率が低くなった可能性がある (Clark 

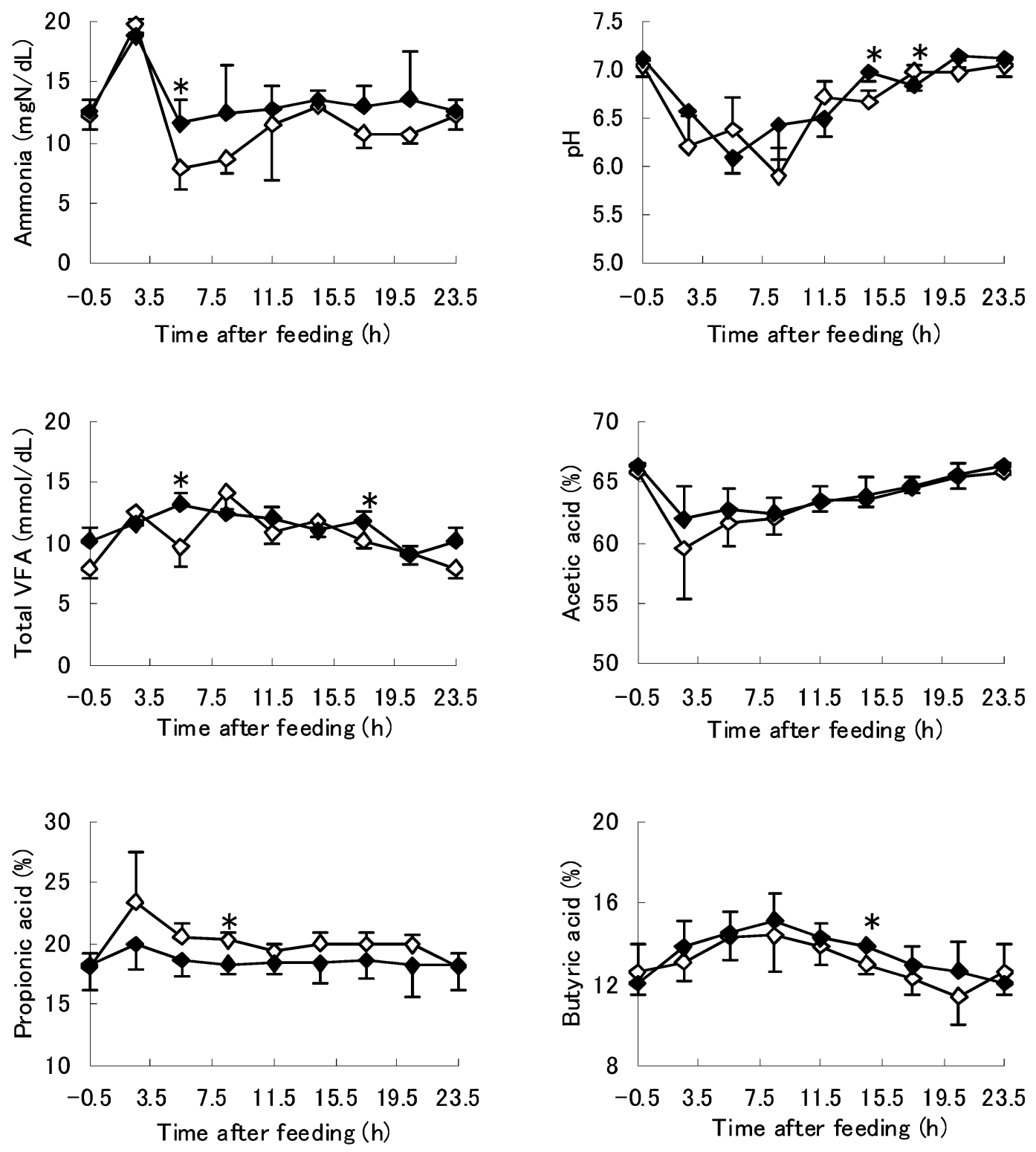

Figure 1 Effects of feeding of mechanically processed corn silage on ruminal $\mathrm{pH}$, concentrations of ammonia-nitrogen and total VFA, and molar proportions of individual VFA in cows fed diets containing unprocessed $(\diamond)$ or processed $(\diamond)$ corn silage.

Vertical bar represents standard deviation.

$*$ : significantly different from unprocessed $(P<0.05)$.

ら 1992).

\section{4. ルーメン $\mathrm{pH}$ および VFA 濃度}

飼料給与 24 時間後までのル一メン液の $\mathrm{pH}$ およびVFA 濃度の推移を図 1 に示す。破砕区はルーメン内デンプン 消化率が高い傾向にあったが $(P=0.08)$, ルーメン液 の $\mathrm{pH}$ は飼料給与後 15～19 時間で有意差があるものの, 区間の差は小さく，それ以外の時間でも区間に差はみら れなかった. Balら (2000) およびSchwabら（2002）は, 破砕処理によりCS N NDF 含量は変化しないが, 未破 砕に比べ，破砕 CS 給与時には乾物摂取量が高まること
により，NDF 摂取量も高まるため，デンプン消化率が高 くてもルーメン液の $\mathrm{pH}$ は変化しないと報告している. 本試験でも破砕区は未破砕区に比べ, NDF 摂取量が高い 傾向にあったため（表 2)，ルーメン内のデンプン消化率 が高かったにも関わらず（表 3)，ルーメン液の $\mathrm{pH}$ は区 間に大きな差がなかった可能性がある.しかし，ルーメ ン液の $\mathrm{pH}$ が最低となった時間は，未破砕区が飼料給与 8.5 時間後であったのに対し, 破砕区は 5.5 時間後と早 く, 破砕処理によってデンプンの消化率とともに, 消化 速度も高まったことが示唆された。 
ルーメン液の総 VFA 濃度は飼料給与 5.5 時間後に破 砕区が高く $(P<0.05)$ ，それ以降は17.5 時間後に有意 差はあるものの区間の差は小さかった。また，VFA 中の 酢酸割合はすべての時間において区間に差はなかった が，破砕区は未破砕区に比べ，プロピオン酸割合が低く， 酪酸割合が高く推移する傾向にあった。本試験と同様 に, Rojas-Bourrillon ら (1987) は, 破砕処理によりVFA 中のプロピオン酸割合が低く, 酪酸割合が高まることを 示した。破砕 CS では，デンプン主体の子実がより利用 されやすい形態となっていると考えられ，デンプン消化 にかかわるルーメン細菌のうち, 酪酸生成菌の割合が高 かった可能性がある.しかし, Dhiman ら（2000）は, 本 試験とは逆に, 破砕処理 CS 給与時にはルーメン液の pH およびVFA 中の酢酸割合が低下し，プロピオン酸割 合が高まることを報告しており，Balら（2000）および Johnsonら（2002b）は, 破砕処理がルーメン液性状に及 ぼす影響は小さいことを示した。破砕処理がルーメン液
性状や微生物相に及ぼす影響については一定の結果が得 られておらず，今後検討が必要である。

\section{5. 咀嚼行動}

咀嚼時間, 採食速度および粗飼料価指数（RVI）を表 5 に示す，反忽時間および総咀嚼時間は区間に差がなかっ たが，破砕区では採食時間が短く $(P<0.01)$, 採食速度 が高かった $(P<0.05)$. Schwabら（2002）も，未破砕 に比べ，破砕処理 CS 給与時には，採食速度が高まるが, 反忽時間は変化しないことを示した。設定切断長が 19 $\mathrm{mm}$ と同じでも，破砕処理すると $19 \mathrm{~mm}$ 以上の飼料片割 合が低下し（Ebling と Kung 2004）, 実平均切断長は 2.25 $\mathrm{mm}$ 短くなることが報告されている (Schwabら 2002). 本試験においても破砕処理によって $19 \mathrm{~mm}$ 以上の飼料 片割合が大きく低下しており，採食時咀嚼が少なくても 嚥下しやすくなり，破砕区で採食速度が高まったと考え られる.

破砕処理により，飼料片粒度は低下するにも関わらず

Table 4 Effects of feeding of mechanically processed corn silage on nitrogen $(N)$ intake, flow of $\mathrm{N}$ fractions to the duodenum and efficiency of microial $\mathrm{N}$ synthesis of cows

\begin{tabular}{|c|c|c|c|c|c|}
\hline & & & \multicolumn{2}{|c|}{ Corn silage } & \multirow{2}{*}{$\begin{array}{l}\text { Significant } \\
\text { difference }^{1}\end{array}$} \\
\hline \multicolumn{3}{|l|}{ Item } & Unprocessed & Processed & \\
\hline \multicolumn{2}{|c|}{$\mathrm{N}$ intake } & (g/day) & $258 \pm 13$ & $295 \pm 15$ & $*$ \\
\hline \multicolumn{2}{|c|}{$\mathrm{N}$ digestibility in the rumen } & $(\%)$ & $81.0 \pm 8.6$ & $79.8 \pm 2.2$ & NS \\
\hline \multicolumn{2}{|c|}{$\mathrm{N}$ digested in the rumen } & (g/day) & $209 \pm 23$ & $235 \pm 13$ & $P=0.09$ \\
\hline \multirow[t]{4}{*}{ Flow to duodenum } & Total N & (g/day) & $159 \pm 8$ & $175 \pm 16$ & $P=0.10$ \\
\hline & $\mathrm{NH}_{3}-\mathrm{N}$ & (g/day) & $6 \pm 1$ & \pm 1 & NS \\
\hline & Microbial N & (g/day) & \pm 17 & \pm 21 & NS \\
\hline & Dietary N & (g/day) & $49 \pm 22$ & $60 \pm 7$ & NS \\
\hline \multicolumn{2}{|c|}{ Efficiency of microial $\mathrm{N}$ synthesis } & $\left(g / k_{g} O M D R^{2}\right)$ & $14.1 \pm 1.2$ & $12.6 \pm 2.3$ & NS \\
\hline
\end{tabular}

Mean \pm standard deviation

${ }^{1} \mathrm{NS}$ : Not significant $(P>0.10), * P<0.05$

${ }^{2}$ OMDR : OM truly digested in the rumen.

Table 5 Effects of feeding of mechanically processed corn silage on chewing activities of cows

\begin{tabular}{|c|c|c|c|c|c|}
\hline \multirow[b]{3}{*}{ Eating time } & \multirow[b]{3}{*}{ (min/day) } & \multicolumn{3}{|c|}{ Corn silage } & \multirow{3}{*}{$\begin{array}{c}\text { Significant } \\
\text { difference }^{1} \\
* *\end{array}$} \\
\hline & & \multicolumn{2}{|c|}{ Unprocessed } & Processed & \\
\hline & & 332 & 18 & \pm 15 & \\
\hline Ruminating time & (min/day) & 488 & \pm 119 & $549 \pm 7$ & NS \\
\hline Total chewing time & (min/day) & $820 \pm$ & \pm 106 & $810 \pm 16$ & NS \\
\hline Intake rate & (gDM/min) & $33.8 \pm$ & $\pm \quad 2.3$ & $48.2 \pm 4.8$ & $*$ \\
\hline $\mathrm{RV} \mathrm{I}^{2}$ & $(\mathrm{~min} / \mathrm{kgDM})$ & $73.1 \pm$ & 7.8 & $64.7 \pm 4.1$ & NS \\
\hline
\end{tabular}

Mean \pm standard deviation

${ }^{1} \mathrm{NS}$ : Not significant $(P>0.10), * P<0.05, * * P<0.01$

${ }^{2} \mathrm{RVI}$ : Roughage value index $=$ Total chewing time (min)/DM intake (kg) 
(Weigand ら 1993 ; Ebling と Kung 2004), 反忽時間は減 少しなかった. De Boeverら（1993）は, 設定切断長を4 $\mathrm{mm}$ から $8 \mathrm{~mm}$ にすると反忽時間は増加するが, $8 \mathrm{~mm}$ 以 上にしても反媰時間はそれ以上増加しないことを示して おり, 本試験の設定切断長は $17 \mathrm{~mm}$ と長く, 破砕処理に よって $9.50 \mathrm{~mm}$ 以上の飼料片割合が低下しても（表 1), 未破砕区と同程度の反忽刺激が確保できたと考えられ る.

本試験で得られた RVI は未破砕区 73.1 分 $/ \mathrm{kg}$, 破砕区 64.7 分 $/ \mathrm{kg}$ で区間に差はなく, CS の設定切断長が $19 \mathrm{~mm}$ のときの RVI は 66.1 分 $/ \mathrm{kg}$ であることを示した Sudweeks ら（1981）の報告と同程度の値であった。咀嚼時間は ルーメン内の緩衝作用を持つ唾液の分泌量と密接に関連 することが知られている (Sudweeks ら 1981). 本試験 において, 破砕区の反媰時間および総咀嚼時間は未破砕 区と同程度であり, 緩衝作用のある唾液が十分に分泌さ れたことより，破砕区はルーメン内のデンプン消化率が 高くても，ルーメン液の $\mathrm{pH}$ が大きく低下しなかった可 能性がある.

\section{6. 結論}

黄熟期のトウモロコシを設定切断長 $17 \mathrm{~mm}$ ， ローラ間 隔 $5 \mathrm{~mm}$ で破砕処理すると，ルーメン内のデンプン消化 率は約 30\% 高い傾向にあったが, NDF 消化率は差がな かった．破砕 CS 給与時には, 総消化管においてもデン プンおよび NFC 消化率が高く, CS の TDN は 3.5\% 向上 した. 以上より, 設定切断長を $17 \mathrm{~mm}$ と長くすることに より, 総咀嚼時間やルーメン液の $\mathrm{pH}$ が適正に維持さ れ, NDF 消化率を低下させずに, デンプンの利用克進が 可能と考えられた. しかし, ルーメン内可消化 OM 量に 対する微生物体窒素合成効率には破砕処理の影響がみら れず，ルーメン内のアンモニア態窒素濃度は破砕 CS 給 与時に高かったことから, 破砕CSに適した併給タンパ ク質飼料の給与方法について検討が必要と考えられる.

\section{謝辞}

本論文を御校閲賜った北海道大学大学院農学研究院の 小林泰男教授に深謝いたします。また，家畜飼養管理お よび研究の補助をしていただいた北海道立畜産試験場病 態生理科の皆様に感謝の意を表します.

なお，本試験は「破砕処理卜ウモロコシサイレージの 第一胃内性状と消化性」(平成 13 年度研究開発調査費課 題（課題番号 118140)）の成果を取りまとめたものであ る.

\section{文献}

Aldrich JM, Muller LD, Varga GA, Griel LC Jr. 1993. Nonstructural carbohydrate and protein effects on rumen fermentation, nutrient flow, and performance of dairy cows. Journal of Dairy Science 76, 1091-1105.

Andrae JG, Hunt CW, Pritchard GT, Kennington LR, Harrison JH,
Kezar W, Mahanna W. 2001. Effect of hybrid, maturity, and mechanical processing of corn silage on intake and digestibility by beef cattle. Journal of Animal Science 79, 2268-2275.

Bal MA, Coors JG, Shaver RD. 1997. Impact of the maturity of corn for use as silage in the diets of dairy cows on intake, digestion, and milk production. Journal of Dairy Science $\mathbf{8 0}$ 2497-2503.

Bal MA, Shaver RD, Jirovec AG, Shinners KJ, Coors JG. 2000. Crop processing and chop length of corn silage : Effects on intake, digestion, and milk production by dairy cows. Journal of Dairy Science 83, 1264-1273.

Clark JH, Klusmeyer TH, Cameron MR. 1992. Microbial protein synthesis and flows of nitrogen fractions to the duodenum of dairy cows. Journal of Dairy Science 75, 2304-2323.

Cooke KM, Bernard JK. 2005. Effect of length of cut and kernel processing on use of corn silage by lactating dairy cows. Journal of Dairy Science 88, 310-316.

De Boever JL, De Brabander DL, De Smet AM, Vanacker JM, Boucque CV. 1993. Evaluation of physical structure. 2. Maize silage. Journal of Dairy Science 76, 1624-1634.

Dhiman TR, Bal MA, Wu Z, Moreira VR, Shaver RD, Satter LD, Shinners KJ, Walgenbach RP. 2000. Influence of mechanical processing on utilization of corn silage by lactating dairy cows. Journal of Dairy Science 83, 2521-2528.

Ebling TL, Kung, Jr. L. 2004. A comparison of processed conventional corn silage to unprocessed and processed brown midrib corn silage on intake, digestion, and milk production by dairy cows. Journal of Dairy Science 87, 2519-2527.

Herrera-Saldana R, Gomez-Alarcon R, Torabi M, and Huber JT. 1990. Influence of synchronizing protein and starch degradation in the rumen on nutrient utilization and microbial protein synthesis. Journal of Dairy Science 73, 142-148.

自給粗飼料品質評価研究会編. 2001. 改訂粗飼料の品質評価力゙ イドブック. pp. 5-40. 社団法人日本草地畜産種子協会, 東 京.

Johnson LM, Harrison JH, Davidson D, Robutti JL, Swift M, Mahanna WC, Shinners K. 2002c. Corn silage management I : Effects of hybrid, maturity, and mechanical processing on chemical and physical characteristics. Journal of Dairy Science 85, 833-853.

Johnson LM, Harrison JH, Davidson D, Swift M, Mahanna WC, Shinners K. 2002a. Corn silage management II : Effects of hybrid, maturity, and mechanical processing on digestion and energy content. Journal of Dairy Science 85, 2913-2927.

Johnson LM, Harrison JH, Davidson D, Swift M, Mahanna WC, Shinners K. 2002b. Corn silage management III : Effects of hybrid, maturity, and mechanical processing on nitrogen metabolism and ruminal fermentation. Journal of Dairy Science 85, 2928-2947.

Kozakai K, Nakamura T, Kobayashi Y, Tanigawa T, Osaka I, Kawamoto S, Hara S. 2007. Effect of mechanical processing of corn silage on in vitro ruminal fermentation, in situ bacterial colonization and dry matter degradation. Canadian Journal of Animal Science 87, 259-267.

National Research Council (NRC). 2001. Nutrients requirements of dairy cattle. 7th revised edn. National Academy Press, Washington DC.

日本分析化学会北海道支部. 1981. 水の分析 (第 3 版). pp. 210 , 358. 化学同人, 北海道.

農業技術研究機構編. 2001. 日本標準飼料成分表 (2001年度 版). pp. 40-46. (独) 農業技術研究機構, 東京. 
Philippeau C, Michalet-Doreau B. 1997. Influence of genotype and stage of maturity of maize on rate of ruminal starch degradation. Animal Feed Science and Technology 98, 25-35.

Rojas-Bourrillon A, Russell JR, Allen Trenkle, McGilliard AD. 1987. Effects of rolling on the composition and utilization by growing steers of whole-plant corn silage. Journal of Animal Science 64, 303-311.

Schwab EC, Shaver RD, Shinners KJ, Lauer JG, Coors JG. 2002. Processing and chop length effects in brown-midrib corn silage on intake, digestion, and milk production by dairy cows. Journal of Dairy Science 85, 613-623.

Smith $\mathrm{RH}$, McAllan AB. 1974. Some factors influencing the chemical composition of mixed rumen bacteria. British Journal of Nutrition 31, 27-34.

Sudweeks EM, Ely LO, Mertens DR, Sisk LR. 1981. Assessing minimum amounts and form of roughages in ruminant diets : roughage value index system. Journal of Animal Science 53,
$1406-1118$.

武政正明. 1992. リン酸カリ試薬による酸化クロム定量法の改 良. 畜産試験場報告 52, 7-13.

谷川珠子, 大坂郁夫, 原 悟志, 川本 哲. 2008. 熟期の異なる とうもろこしサイレージの給与が乳牛の炭水化物および夕 ンパク質利用性に及ぼす影響. 日本畜産学会報 79, 29-35.

Weigand E, Meyer U, Guth N. 1993. Intake, chewing activity and carbohydrate digestibility by lactating dairy cows fed maize silage with a different physical structure. Journal of Animal Physiology and Animal Nutrition 69, 120-132.

Weiss WP, Wyatt DJ. 2000. Effect of oil content and kernel processing of corn silage on digestibility and milk production by dairy cows. Journal of Dairy Science 83, 351-358.

Zinn RA, Owens FN. 1986. A rapid procedure for purine measurement and its use for estimating net ruminal protein synthesis. Canadian Journal of Animal Science 66, 157-166.

\title{
Effects of feeding of mechanically processed corn silage on carbohydrate and protein utilization in dairy cows
}

\author{
Tamako TANIGAWA ${ }^{1}$, Ikuo OOSAKA², Satoshi KAWAMOTO ${ }^{1}$ and Satoshi HARA ${ }^{1}$ \\ ${ }^{1}$ Hokkaido Animal Research Center, Shintoku, Hokkaido 081-0038, Japan \\ ${ }^{2}$ Hokkaido Central Agricultural Experiment Station, Naganuma, Hokkaido 069-1395, Japan
}

Corresponding : Tamako TANIGAWA (fax : +81 (0) 156-64-5349, e-mail : t.tanigawa@agri.pref.hokkaido.jp)

The object of this study was to evaluate the effects of feeding of mechanically processed corn silage (CS) on carbohydrate and protein utilization in cows. CS was prepared by harvesting field corn at yellow ripe stage of maturity in $17 \mathrm{~mm}$ theoretical length of cut (TLC) with or without subsequent kernel processing using steel rollers set at $5 \mathrm{~mm}$ width and ensiling in a bunker silo (processed and unprocessed CS, respectively). CS was given to three ruminally and duodenally canulated dry cows with soybean meal to equalize crude protein supply. Mechanical processing did not affect chemical composition of CS. DM, crude protein and starch intake of processed CS were significantly higher $(P<0.05)$ than those of unprocessed CS. Ruminal digestibility of starch tended to increase $(P=0.08)$ by mechanical processing, though that of neutral detergent fiber was not affected. Total tract digestibility of starch and content of total digestible nutrients of processed CS were significantly higher $(P<0.05)$ than those of unprocessed CS. Efficiency of microbial nitrogen synthesis was not affected by mechanical processing. Ruminal $\mathrm{pH}$ and ruminating time were not affected by mechanical processing, while eating rate was significantly higher $(P<0.05)$ when processed CS was fed. The results suggest that mechanical processing with $17 \mathrm{~mm}$ TLC increased utilization of starch without detracting total chewing time of cows.

Nihon Chikusan Gakkaiho 81 (1), 11-19, 2010 Key words : corn silage, dairy cow, digestibility, mechanical processing, microbial nitrogen synthesis. 